\title{
Cryptic diversity in Mediterranean gastropods of the genus Aplus (Neogastropoda: Buccinidae)
}

\author{
Chrifa Aissaoui ${ }^{1,4}$, Nicolas Puillandre ${ }^{2}$, Philippe Bouchet ${ }^{1}$, Giulia Fassio ${ }^{3}$, \\ Maria Vittoria Modica ${ }^{3}$, Marco Oliverio $^{3}$ \\ ${ }^{1}$ Institut de Systématique, Évolution, Biodiversité ISYEB - UMR 7205 - CNRS, MNHN, UPMC, EPHE, Muséum national \\ d'Histoire naturelle, Sorbonne Universités, 55 rue Buffon, F-75231, Paris, France. \\ ${ }^{2}$ Institut de Systématique, Évolution, Biodiversité ISYEB - UMR 7205 - CNRS, MNHN, UPMC, EPHE, Muséum national \\ d'Histoire naturelle, Sorbonne Universités, 43 rue Cuvier, F-75231, Paris, France. \\ ${ }^{3}$ Dipartimento di Biologia e Biotecnologie "Charles Darwin”, 'Sapienza' Università di Roma, Viale dell'Università 32, \\ I-00185 Roma, Italy. E-mail: marco.oliverio@uniroma1.it \\ ${ }^{4}$ Université de Carthage, Faculté des Sciences de Bizerte, Laboratoire de Biosurveillance de l'Environnement \\ (Unité. Hydrobiologie littorale et limnique), 7021 Jarzouna, Tunisie.
}

\begin{abstract}
Summary: Northeastern Atlantic and Mediterranean gastropods previously ascribed to the buccinid genus Pollia Gray, 1837 are more correctly classified in the genus Aplus de Gregorio, 1885. Using an integrative taxonomy approach combining molecular, morphological and geographic data, we revisit the limits of the extant species in the area, and propose a molecular phylogenetic hypothesis based on 66 specimens from various localities in the Mediterranean Sea, including type localities of some nominal taxa. We used a preliminary morphological inspection, followed by a DNA-barcoding approach to propose species hypotheses, subsequently consolidated using additional data (phylogenetic, geographic and refined morphological data). Seven species hypotheses were eventually retained within our molecularly assayed samples, versus three classical morphologically recognized species. Among these, three correspond to Aplus dorbignyi (Payreaudeau, 1826) with its hitherto unrecognized geographical cognates A. gaillardoti (Puton, 1856) (eastern Mediterranean) and Aplus nodulosus (Bivona Ant., 1832) (Sicily); two closely related, yet considerably divergent, lineages are treated as a single species under Aplus scaber (Locard, 1892); the classically admitted Aplus scacchianus (Philippi, 1844) is confirmed by molecular evidence; Mediterranean populations attributable to Aplus assimilis (Reeve, 1846) may represent either cryptic native populations or an ongoing invasion of the Mediterranean by what was hitherto considered to be a West African species; finally, specimens from the Strait of Gibraltar may represent an undescribed species, but we conservatively refrain from formally introducing it pending the analysis of more material, and it is compared with the similar Aplus campisii (Ardovini, 2014), recently described from Sicily and not assayed molecularly, and Aplus scaber.
\end{abstract}

Keywords: Mollusca; gastropoda; cryptic species; DNA-barcoding; taxonomy.

Diversidad críptica en gasterópodos mediterráneos del género Aplus (Neogastropoda: Buccinidae)

Resumen: Los gasterópodos mediterráneos y del Atlántico nordeste previamente asignados al género Pollia Gray, 1837 deben ser más correctamente incluidos en el género Aplus de Gregorio, 1885. Se revisan aquí los límites de las especies recientes de este género en el área estudiada por medio de un enfoque de taxonomía integrativa. En base a ello se propone una hipótesis filogenética basada en 66 ejemplares procedentes de varias localidades del Mediterráneo, incluyendo las localidades tipo de algunos taxones nominales. Primero se realizó una diferenciación morfológica, seguida de la aplicación del marcador molecular COI para proponer las especies a modo de hipótesis, que finalmente fueron validadas con datos adicionales (filogenéticos, geográficos y detalles morfológicos). Como resultado se reconocieron siete especies válidas entre los ejemplares analizados molecularmente, en contraste con las tres especies previamente reconocidas morfológicamente. Tres de ellas corresponden a Aplus dorbignyi (Payreaudeau, 1826) y a sus afines geográficos no reconocidas hasta ahora $A$. gaillardoti (Puton, 1856) [del Mediterráneo oriental] y Aplus nodulosus (Bivona Ant., 1832) [de Sicilia]; dos linajes estrechamente relacionados, aunque divergentes, son considerados como una misma especie con el nombre de Aplus scaber (Locard, 1892); la especie tradicionalmente admitida Aplus scacchianus (Philippi, 1844) se confirma en base a evidencias moleculares; las poblaciones mediterráneas atribuibles a Aplusas similis (Reeve, 1846) pueden ser crípticas nativas o corresponder a una invasión en curso por parte de esta especie del noroeste africano; finalmente los ejemplares del Estrecho de Gibraltar pueden representar una especie no descrita, pero se ha preferido optar por una posición conservadora y no introducir un nuevo nombre a la espera del estudio de material adicional y compararla con Aplus campisii (Ardovini, 2014), especie descrita recientemente de Sicilia y pendiente de su análisis molecular, y con Aplus scaber.

Palabras clave: Mollusca; gastropoda; especies crípticas; DNA-barcode; taxonomía.

Citation/Como citar este artículo: Aissaoui C., Puillandre N., Bouchet P., Fassio G., Modica M.V., Oliverio M. 2016. Cryptic diversity in Mediterranean gastropods of the genus Aplus (Neogastropoda: Buccinidae). Sci. Mar. 80(4): 521-533. doi: http://dx.doi.org/10.3989/scimar.04422.12A 
Editor: J. Templado.

Received: February 11, 2016. Accepted: May 6, 2016. Published: October 17, 2016.

Copyright: ( $) 2016$ CSIC. This is an open-access article distributed under the terms of the Creative Commons Attribution (CC-by) Spain 3.0 License.

\section{INTRODUCTION}

The Buccinidae Rafinesque, 1815 are a diverse family of medium to large scavenging gastropods living on soft or hard bottoms from the shore to the deep sea and from the tropics to the polar regions. Currently some 100 genera and 1140 species are recognized worldwide (Bouchet and Gofas 2015), with suprageneric systematics still poorly defined (Hayashi 2005). Traditionally, small buccinids with one or more internal denticles on the outer lip are allocated to genus-level taxa such as Pollia Gray, 1834, Cantharus Röding, 1798, or Tritonidea Swainson, 1840, which have mainly Indo-West Pacific distributions (Vermeij 2006, García 2008, Vermeij and Bouchet 1998). Five eastern Atlantic and Mediterranean species are currently included in the genus Pollia (Settepassi 1971, Giannuzzi-Savelli et al. 2003, Vermeij 2006, Brunetti and Della Bella 2014): the classically recognized $P$. dorbignyi (Payraudeau, 1826), P. scacchiana (Philippi, 1844) and P. scabra Locard, 1892, and two "outliers", Pollia assimilis (Reeve, 1846), thought to be a West African species, and the recently described $P$. campisii Ardovini, 2015 from Sicily. Gofas and Le Renard (2015) included also Pollia viverratoides (d'Orbigny, 1840), which is, however, placed (more correctly) in the genus Gemophos in WoRMS.

Vermeij (2006) and García (2008) proposed to use for these species the genus name Anna Risso, 1826 (type species Anna massena Risso, 1826, by monotypy). However, Anna massena (a Pliocene species from SE France) is probably a species of Raphitomidae (Conoidea; Brunetti and Della Bella 2014: 12, S. Gofas pers. comm.) and the use of the name Anna for these buccinids was rejected by Brunetti and Della Bella (2014), who instead convincingly suggested that Buccinum dorbignyi and related species belong to a lineage well represented in the Plio-Pleistocene of Europe, distinct from Pollia, for which the genus name Aplus de Gregorio, 1885 is available. Very similar species are known from the western Atlantic, for which Landau and Vermeij (2012) erected the new genus Ameranna (type species Anna florida García, 2008, Recent, Florida).

Mediterranean Aplus show a noteworthy morphological variation that is congruent with their mode of development. Their paucispiral protoconchs indicate a lecithotrophic larval development (probably entirely or mostly intracapsular), and therefore with a very limited dispersal ability, as is common in many buccinids (Amio 1963, Golikov 1980, Webber 1977). Historically, shelled gastropod taxonomy has been almost entirely based on shell characters, which are still commonly used, though morphological variation caused by adaptation to environmental pressures has been documented (Vermeij 2006). An exclusively tra- ditional morphological taxonomy has shown its limits, and recent studies on marine molluscs have integrated molecular and traditional approaches to resolve taxonomic questions (e.g. Puillandre et al. 2009, Claremont et al. 2011, Zou et al. 2012).

The objectives of the present study were to apply an integrative taxonomy approach, combining molecular, morphological and geographical distribution data, based on 66 sequenced specimens from the Mediterranean Sea (including topotypical material of several nominal taxa) in order to define limits of Aplus species and to evaluate the presence of cryptic lineages.

\section{MATERIALS AND METHODS}

\section{Samples and morphological primary identifications}

Samples were collected at different Mediterranean localities (Fig. 1) and were fixed and preserved in absolute ethanol for molecular analysis. The soft parts were extracted from the shell; the shell was photographed and retained as a voucher (MNHN: Muséum national d'Histoire naturelle, Paris; BAU: Department of Biology and Biotechnologies, "Charles Darwin", "Sapienza' University, Rome). The collecting locality data, voucher numbers and GenBank accession numbers for each specimen are reported in Table 1. The material included in this paper was morphologically identified by Gianni Spada and Marco Oliverio according to the current morphological interpretation of Mediterranean Aplus (see e.g. Scaperrotta et al. 2012, who also figured the growth stages of A. dorbignyi, A. scaber and A. scacchianus). Protoconch whorls were counted with

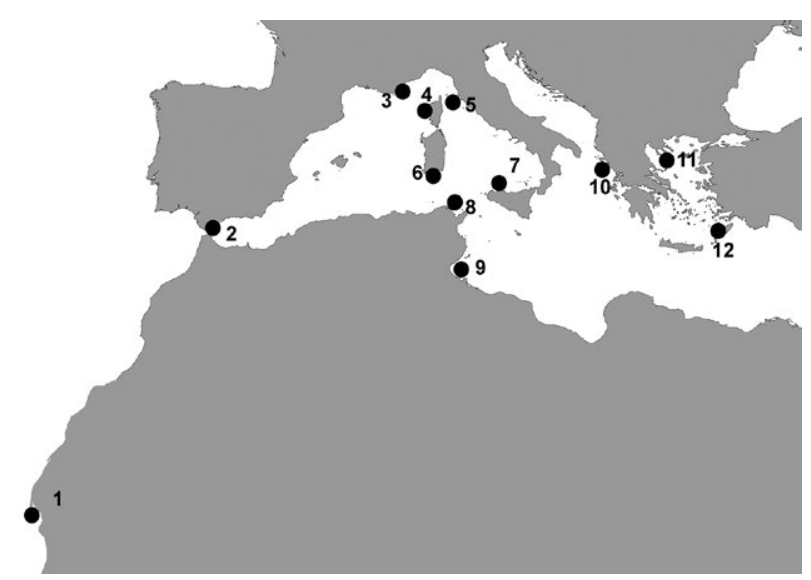

Fig. 1. - Map showing sampling sites where molecular material was obtained (see Table 1 for details). 1, Cap Tafarit, Mauritania. 2, Tarifa Island, Spain. 3, Saint Raphaël, France. 4, Calcataggio, Corsica. 5, Elba Island, Italy. 6, Su Siccu, Sardinia. 7, Palermo, Sicily. 8. Bizerte, Tunisia. 9, Djerba Is., Tunisia. 10, Paxos Is., Greece. 11, Marmaros, Halkidiki, Greece. 12, Astypalea Is., Greece. 
Table 1. - List of the examined material with collection localities (in parentheses the number in Figure 1), vouchers ID numbers (BAU: Department of Biology and Biotechnologies, 'Sapienza' University, Rome. IM: Muséum national d'Histoire naturelle, Paris) and GenBank accession numbers for the sequences.

\begin{tabular}{|c|c|c|c|}
\hline $\begin{array}{l}\text { Updated taxonomic } \\
\text { identification }\end{array}$ & Voucher No. & Locality & $\begin{array}{c}\text { GenBank } \\
\text { Acc. no. }\end{array}$ \\
\hline Aplus dorbignyi & BAU-1610 & (4) Galeria, Corsica, France, $42^{\circ} 02^{\prime} 36^{\prime \prime} \mathrm{N}, 8^{\circ} 43^{\prime} 15^{\prime \prime} \mathrm{E} 4 \mathrm{~m}$ depth & KX089291 \\
\hline \multirow{16}{*}{ (Payraudeau 1826) } & BAU-1625.1 & (4) Tour d'Ancône, Calcatoggio, Corsica, France, $42^{\circ} 02^{\prime} 36^{\prime \prime} \mathrm{N} 8^{\circ} 43^{\prime} 15^{\prime \prime} \mathrm{E}, 2-4 \mathrm{~m}$ depth & KX089292 \\
\hline & BAU-1625.2 & (4) Tour d'Ancône, Calcatoggio, Corsica, France, $42^{\circ} 02^{\prime} 36^{\prime \prime} \mathrm{N} 8^{\circ} 43^{\prime} 15^{\prime \prime} \mathrm{E}, 2-4 \mathrm{~m}$ depth & KX089293 \\
\hline & BAU-1625.3 & (4) Tour d'Ancône, Calcatoggio, Corsica, France, $42^{\circ} 02^{\prime} 36^{\prime \prime} \mathrm{N} 8^{\circ} 43^{\prime} 15^{\prime \prime} \mathrm{E}, 2-4 \mathrm{~m}$ depth & KX089294 \\
\hline & IM-2009-30810 & (9) Djerba, Mellita, Tunisia, $33^{\circ} 51.660^{\prime} \mathrm{N}, 10^{\circ} 44.83^{\prime} \mathrm{E}, 1-3 \mathrm{~m}$ depth & KX089266 \\
\hline & IM-2013-30811 & (9) Djerba, Mellita, Tunisia, $33^{\circ} 51.660^{\prime} \mathrm{N}, 10^{\circ} 44.83^{\prime} \mathrm{E}, 1-3 \mathrm{~m}$ depth & KX089267 \\
\hline & IM-2013-31696 & (9) Djerba, Borjj Djillij, Tunisia, 33⒌ $52.9^{\prime} \mathrm{N}, 10^{\circ} 44.6^{\prime} \mathrm{E}, 1-2 \mathrm{~m}$ depth & KX089268 \\
\hline & IM-2013-31697 & (9) Djerba, Borjj Djillij, Tunisia, $33^{\circ} 52.9^{\prime} \mathrm{N}, 10^{\circ} 44.6^{\prime} \mathrm{E}, 1-2 \mathrm{~m}$ depth & KX089269 \\
\hline & IM-2013-31698 & (9) Djerba, Borjj Djillij, Tunisia, $33^{\circ} 52.9^{\prime} \mathrm{N}, 10^{\circ} 44.6^{\prime} \mathrm{E}, 1-2 \mathrm{~m}$ depth & KX089270 \\
\hline & IM-2013-31717 & (9) Djerba, Borjj Djillij, Tunisia, $33^{\circ} 52.9^{\prime} \mathrm{N}, 10^{\circ} 44.6^{\prime} \mathrm{E}, 1-2 \mathrm{~m}$ depth & KX089271 \\
\hline & IM-2013-31740 & (9) Djerba, oumet Souk, Tunisia, $33^{\circ} 54^{\prime} \mathrm{N}, 10^{\circ} 48^{\prime} \mathrm{E}, 1-2 \mathrm{~m}$ depth & KX089272 \\
\hline & IM-2013-31841 & (9) Djerba, Sidi Jmour, Tunisia, $33^{\circ} 49.88^{\prime} \mathrm{N}, 10^{\circ} 44.83^{\prime} \mathrm{E}, 1-3 \mathrm{~m}$ depth & KX089273 \\
\hline & IM-2013-31842 & (9) Djerba, Sidi Jmour, Tunisia, $33^{\circ} 49.88^{\prime} \mathrm{N}, 10^{\circ} 44.83^{\prime} \mathrm{E}, 1-3 \mathrm{~m}$ depth & KX089274 \\
\hline & IM-2013-31931 & (9) Djerba, Sidi Souliman, Tunisia, $33^{\circ} 50^{\prime} \mathrm{N}, 11^{\circ} 01,07^{\prime} \mathrm{E}, 1-2 \mathrm{~m}$ depth & KX089275 \\
\hline & IM-2013-31932 & (9) Djerba, Sidi Souliman, Tunisia, $33^{\circ} 50^{\prime} \mathrm{N}, 11^{\circ} 01.07^{\prime} \mathrm{E}, 1-2 \mathrm{~m}$ depth & KX089276 \\
\hline & IM-2013-32077 & (9) Djerba, Sidi Jmour, Tunisia, $33^{\circ} 49.88^{\prime} \mathrm{N}, 10^{\circ} 44.83^{\prime} \mathrm{E}, 1-3 \mathrm{~m}$ depth & KX089277 \\
\hline & IM-2013-32078 & (9) Djerba, Sidi Jmour, Tunisia, $33^{\circ} 49.88^{\prime} \mathrm{N}, 10^{\circ} 44.83^{\prime} \mathrm{E}, 1-3 \mathrm{~m}$ depth & KX089278 \\
\hline Aplus scaber & IM-2013-31912 & (9) Djerba, Sidi Solimen, Tunisia, $33^{\circ} 50^{\prime} \mathrm{N}, 11^{\circ} 01.07^{\prime} \mathrm{E}, 1-2 \mathrm{~m}$ depth & KX089323 \\
\hline \multirow[t]{3}{*}{ (Locard, 1892) } & IM-2013-31913 & (9) Djerba, Sidi Solimen, Tunisia, $33^{\circ} 50^{\prime} \mathrm{N}, 11^{\circ} 01.07^{\prime} \mathrm{E}, 1-2 \mathrm{~m}$ depth & KX089322 \\
\hline & IM-2013-32884 & (3) Saint Raphaël, France, $43^{\circ} 25.32^{\prime} \mathrm{N}, 06^{\circ} 53^{\prime} 69^{\prime} \mathrm{E}$ & KX089328 \\
\hline & IM-2013-32885 & (3) Saint Raphaël, France, $43^{\circ} 25.32^{\prime} \mathrm{N}, 06^{\circ} 53^{\prime} 69^{\prime} \mathrm{E}$ & KX089327 \\
\hline \multirow[t]{3}{*}{ Aplus sp. } & IM-2009-5217 & (2) Isla de Tarifa, Cadiz, Spain, $36^{\circ} 0^{\prime} 11.7^{\prime \prime} \mathrm{N}, 05^{\circ} 36^{\prime} 37.1^{\prime \prime} \mathrm{W}$ & KX089326 \\
\hline & IM-2009-5218 & (2) Isla de Tarifa, Cadiz, Spain, $36^{\circ} 0^{\prime} 11.7^{\prime \prime} \mathrm{N}, 05^{\circ} 36^{\prime} 37.1^{\prime \prime} \mathrm{W}$ & KX089324 \\
\hline & IM-2009-5219 & (2) Isla de Tarifa, Cadiz, Spain, $36^{\circ} 0^{\prime} 11.7^{\prime \prime} \mathrm{N}, 05^{\circ} 36^{\prime} 37.1^{\prime \prime} \mathrm{W}$ & KX089325 \\
\hline Aplus assimilis & BAU-2215.1 & (1) Cap Tafarit, Mauritania, $20^{\circ} 07^{\prime} 36.50^{\prime \prime} \mathrm{N}, 16^{\circ} 15^{\prime} 25.14^{\prime \prime} \mathrm{W}$, intertidal & KX138226 \\
\hline \multirow[t]{17}{*}{ (Reeve, 1846) } & BAU-2215.2 & (1) Cap Tafarit, Mauritania, $20^{\circ} 07^{\prime} 36.50^{\prime \prime} \mathrm{N}, 16^{\circ} 15^{\prime} 25.14^{\prime \prime} \mathrm{W}$, intertidal & KX138227 \\
\hline & BAU-2218.1 & (6) Su Siccu, Cagliari, Sardinia, Italy, $39^{\circ} 12^{\prime} \mathrm{N} 9^{\circ} 06^{\prime} \mathrm{E}, 0-1 \mathrm{~m}$ depth & KX138228 \\
\hline & BAU-2218.2 & (6) Su Siccu, Cagliari, Sardinia, Italy, $39^{\circ} 12^{\prime} \mathrm{N} 9^{\circ} 06^{\prime} \mathrm{E}, 0-1 \mathrm{~m}$ depth & KX138229 \\
\hline & BAU-2218.3 & (6) Su Siccu, Cagliari, Sardinia, Italy, $39^{\circ} 12^{\prime} \mathrm{N} 9^{\circ} 06^{\prime} \mathrm{E}, 0-1 \mathrm{~m}$ depth & KX138230 \\
\hline & BAU-2218.4 & (6) Su Siccu, Cagliari, Sardinia, Italy, $39^{\circ} 12^{\prime} \mathrm{N} 9^{\circ} 06^{\prime} \mathrm{E}, 0-1 \mathrm{~m}$ depth & KX138231 \\
\hline & BAU-2218.5 & (6) Su Siccu, Cagliari, Sardinia, Italy, $39^{\circ} 12^{\prime} \mathrm{N} 9^{\circ} 06^{\prime} \mathrm{E}, 0-1 \mathrm{~m}$ depth & KX138232 \\
\hline & IM-2013-32225 & (8) Bizerte, Menzel Jmil, Tunisia, $37^{\circ} 13.17^{\prime} \mathrm{N}, 9^{\circ} 54.34^{\prime} \mathrm{E}, 0-1 \mathrm{~m}$ depth & KX089305 \\
\hline & IM-2013-32227 & (8) Bizerte, Menzel Jmil, Tunisia, $37^{\circ} 13.17^{\prime} \mathrm{N}, 9^{\circ} 54.34^{\prime} \mathrm{E}, 0-1 \mathrm{~m}$ depth & KX089306 \\
\hline & IM-2013-32228 & (8) Bizerte, Menzel Jmil, Tunisia, $37^{\circ} 13.17^{\prime} \mathrm{N}, 9^{\circ} 54.34^{\prime} \mathrm{E}, 0-1 \mathrm{~m}$ depth, & KX089307 \\
\hline & IM-2013-32233 & (8) Bizerte, Menzel Jmil, Tunisia, $37^{\circ} 13.17^{\prime} \mathrm{N}, 9^{\circ} 54.34^{\prime} \mathrm{E}, 0-1 \mathrm{~m}$ depth & KX089308 \\
\hline & IM-2013-32254 & (8) Bizerte, Menzel Jmil, Tunisia, $37^{\circ} 13.17^{\prime} \mathrm{N}, 9^{\circ} 54.34^{\prime} \mathrm{E}, 0-1 \mathrm{~m}$ depth & KX089309 \\
\hline & IM-2013-32274 & (8) Bizerte, Menzel Jmil, Tunisia, $37^{\circ} 13.17^{\prime} \mathrm{N}, 9^{\circ} 54.34^{\prime} \mathrm{E}$ & KX089310 \\
\hline & IM-2013-32513 & (8) Bizerte, Menzel Abderrahmen, Tunisia, $37^{\circ} 15.51^{\prime} \mathrm{N}, 9^{\circ} 51.32^{\prime} \mathrm{E}$ & KX089311 \\
\hline & IM-2013-32561 & (8) Bizerte, Errimel, Tunisia, $37^{\circ} 45.76^{\prime} \mathrm{N}, 9^{\circ} 56.17^{\prime} \mathrm{E}, 0-1 \mathrm{~m}$ depth & KX089312 \\
\hline & IM-2013-32564 & (8) Bizerte, Errimel, Tunisia, $37^{\circ} 45.76^{\prime} \mathrm{N}, 9^{\circ} 56.17^{\prime} \mathrm{E}, 0-1 \mathrm{~m}$ depth & KX089313 \\
\hline & IM-2013-32565 & (8) Bizerte, Errimel, Tunisia, $37^{\circ} 45.76^{\prime} \mathrm{N}, 9^{\circ} 56.17^{\prime} \mathrm{E}, 0-1 \mathrm{~m}$ depth & KX089314 \\
\hline & IM-2013-32586 & (8) Bizerte, Errimel, Tunisia, $37^{\circ} 45.76^{\prime} \mathrm{N}, 9^{\circ} 56.17^{\prime} \mathrm{E}, 0-1 \mathrm{~m}$ depth & KX089315 \\
\hline & BAU-1500 & (12) Analipsi, Astypalea Is., Greece, $36^{\circ} 34^{\prime} 25^{\prime \prime} \mathrm{N}, 26^{\circ} 23^{\prime} 02^{\prime \prime} \mathrm{E}, 1-7 \mathrm{~m}$ depth & KX089280 \\
\hline \multirow{15}{*}{ (Puton, 1856) } & BAU-1509.1 & (12) Analipsi, Astypalea Is., Greece, $36^{\circ} 34^{\prime} 25^{\prime \prime} \mathrm{N}, 26^{\circ} 23^{\prime} 02^{\prime \prime} \mathrm{E}, 1-7 \mathrm{~m}$ depth & KX089279 \\
\hline & BAU-1509.2 & (12) Analipsi, Astypalea Is., Greece, $36^{\circ} 34^{\prime} 25^{\prime \prime} \mathrm{N}, 26^{\circ} 23^{\prime} 02^{\prime \prime} \mathrm{E}, 1-7 \mathrm{~m}$ depth & KX089281 \\
\hline & BAU-1509.3 & (12) Analipsi, Astypalea Is., Greece, $36^{\circ} 34^{\prime} 25^{\prime \prime} \mathrm{N}, 26^{\circ} 23^{\prime} 02^{\prime \prime} \mathrm{E}, 1-7 \mathrm{~m}$ depth & KX089282 \\
\hline & BAU-1558.1 & (12) Mikro-Vai, Astypalea Is. Greece, $36^{\circ} 36^{\prime} 11^{\prime \prime} \mathrm{N}, 26^{\circ} 23^{\prime} 38^{\prime \prime} \mathrm{E}, 1-7 \mathrm{~m}$ depth & KX089283 \\
\hline & BAU-1558.2 & (12) Mikro-Vai, Astypalea Is. Greece, $36^{\circ} 36^{\prime} 11^{\prime \prime} \mathrm{N}, 26^{\circ} 23^{\prime} 38^{\prime \prime} \mathrm{E}, 1-7 \mathrm{~m}$ depth & KX089284 \\
\hline & BAU-1558.3 & (12) Mikro-Vai, Astypalea Is. Greece, $36^{\circ} 36^{\prime} 11^{\prime \prime N}, 26^{\circ} 23^{\prime} 38^{\prime \prime} \mathrm{E}, 1-7 \mathrm{~m}$ depth & KX089285 \\
\hline & BAU-1558.4 & (12) Mikro-Vai, Astypalea Is. Greece, $36^{\circ} 36^{\prime} 11^{\prime \prime} \mathrm{N}, 26^{\circ} 23^{\prime} 38^{\prime \prime} \mathrm{E}, 1-7 \mathrm{~m}$ depth & KX089286 \\
\hline & BAU-1558.5 & (12) Mikro-Vai, Astypalea Is. Greece, $36^{\circ} 36^{\prime} 11^{\prime \prime} \mathrm{N}, 26^{\circ} 23^{\prime} 38^{\prime \prime} \mathrm{E}, 1-7 \mathrm{~m}$ depth & KX089287 \\
\hline & BAU-1558.6 & (12) Mikro-Vai, Astypalea Is. Greece, $36^{\circ} 36^{\prime} 11^{\prime \prime N}, 26^{\circ} 23^{\prime} 38^{\prime \prime} \mathrm{E}, 1-7 \mathrm{~m}$ depth & KX089288 \\
\hline & BAU-1558.7 & (12) Mikro-Vai, Astypalea Is. Greece, $36^{\circ} 36^{\prime} 11^{\prime \prime} \mathrm{N}, 26^{\circ} 23^{\prime} 38^{\prime \prime} \mathrm{E}, 1-7 \mathrm{~m}$ depth & KX089289 \\
\hline & BAU-1575.3 & (12) Kotsoumiti Is., Greece, $36^{\circ} 32^{\prime} 49^{\prime \prime} \mathrm{N}, 26^{\circ} 26^{\prime} 36^{\prime \prime} \mathrm{E}, 1-12 \mathrm{~m}$ depth & KX089290 \\
\hline & IM-2013-32773 & (10) Paxos Island, Greece, $39^{\circ} 12.591^{\prime} \mathrm{N}, 20^{\circ} 9.488^{\prime} \mathrm{E}, 1-2 \mathrm{~m}$ depth & KX089317 \\
\hline & IM-2013-32774 & (10) Paxos Island, Greece, $39^{\circ} 12.591^{\prime} \mathrm{N}, 20^{\circ} 9.488^{\prime} \mathrm{E}, 1-2 \mathrm{~m}$ depth & KX089318 \\
\hline & IM-2013-32775 & (10) Paxos Island, Greece, $39^{\circ} 12.591^{\prime} \mathrm{N}, 20^{\circ} 9.488^{\prime} \mathrm{E}, 1-2 \mathrm{~m}$ depth & KX089319 \\
\hline & IM-2013-32778 & (10) Paxos Island, Greece, $39^{\circ} 12.591^{\prime} \mathrm{N}, 20^{\circ} 9.488^{\prime} \mathrm{E}, 1-2 \mathrm{~m}$ depth & KX089320 \\
\hline Aplus scacchianus & BAU-1510.1 & (12) Analipsi, Astypalea Is., Greece, $36^{\circ} 34^{\prime} 25^{\prime \prime} \mathrm{N}, 26^{\circ} 23^{\prime} 02^{\prime \prime} \mathrm{E}, 1-7 \mathrm{~m}$ depth & KX089295 \\
\hline \multirow[t]{11}{*}{ (Philippi, 1844) } & BAU-1510.2 & (12) Analipsi, Astypalea Is., Greece, $36^{\circ} 34^{\prime} 25^{\prime \prime} \mathrm{N}, 26^{\circ} 23^{\prime} 02^{\prime \prime} \mathrm{E}, 1-7 \mathrm{~m}$ depth & KX089296 \\
\hline & BAU-1510.3 & (12) Analipsi, Astypalea Is., Greece, $36^{\circ} 34^{\prime} 25^{\prime \prime} \mathrm{N}, 26^{\circ} 23^{\prime} 02^{\prime \prime} \mathrm{E}, 1-7 \mathrm{~m}$ depth & KX089297 \\
\hline & BAU-1510.4 & (12) Analipsi, Astypalea Is., Greece, $36^{\circ} 34^{\prime} 25^{\prime \prime} \mathrm{N}, 26^{\circ} 23^{\prime} 02^{\prime \prime} \mathrm{E}, 1-7 \mathrm{~m}$ depth & KX089298 \\
\hline & BAU-1510.5 & (12) Analipsi, Astypalea Is., Greece, $36^{\circ} 34^{\prime} 25^{\prime \prime} \mathrm{N}, 26^{\circ} 23^{\prime} 02^{\prime \prime} \mathrm{E}, 1-7 \mathrm{~m}$ depth & KX089299 \\
\hline & BAU-1510.6 & (12) Analipsi, Astypalea Is., Greece, $36^{\circ} 34^{\prime} 25^{\prime \prime} \mathrm{N}, 26^{\circ} 23^{\prime} 02^{\prime \prime} \mathrm{E}, 1-7 \mathrm{~m}$ depth & KX089300 \\
\hline & BAU-1551.1 & (12) Vai, Astypalea Is., Greece, $36^{\circ} 35^{\prime} 13^{\prime \prime} \mathrm{N}, 26^{\circ} 24^{\prime} 10^{\prime \prime} \mathrm{E}, 1-7 \mathrm{~m}$ depth & KX089301 \\
\hline & BAU-1551.2 & (12) Vai, Astypalea Is., Greece, $36^{\circ} 35^{\prime} 13^{\prime \prime} \mathrm{N}, 26^{\circ} 24^{\prime} 10^{\prime \prime} \mathrm{E}, 1-7 \mathrm{~m}$ depth & KX089302 \\
\hline & BAU-1551.3 & (12) Vai, Astypalea Is., Greece, $36^{\circ} 35^{\prime} 13^{\prime \prime} \mathrm{N}, 26^{\circ} 24^{\prime} 10^{\prime \prime} \mathrm{E}, 1-7 \mathrm{~m}$ depth & KX089303 \\
\hline & BAU-1551.4 & (12) Vai, Astypalea Is., Greece, $36^{\circ} 35^{\prime} 13^{\prime \prime} \mathrm{N}, 26^{\circ} 24^{\prime} 10^{\prime \prime} \mathrm{E}, 1-7 \mathrm{~m}$ depth & KX089304 \\
\hline & IM-2013-32673 & (5) Elba Is., Italy, $42^{\circ} 44.49^{\prime} \mathrm{N}, 10^{\circ} 9.34^{\prime} \mathrm{E}$ & KX089321 \\
\hline & IM-2013-32771 & (11) Neos Marmaras, Halkidiki, Greece, $40^{\circ} 22.901^{\prime} \mathrm{N}, 23^{\circ} 26.56^{\prime} \mathrm{E}$ & KX089316 \\
\hline & IM-2013-32877 & (7) Palermo, Sicily, Italy, $38^{\circ} 6.941^{\prime} \mathrm{N}, 13^{\circ} 21.676^{\prime} \mathrm{E}$ & KX089329 \\
\hline \multirow[t]{2}{*}{ (Bivona Ant., 1832) } & IM-2013-32878 & (7) Palermo, Sicily, Italy, $38^{\circ} 6.941^{\prime} \mathrm{N}, 13^{\circ} 21.676^{\prime} \mathrm{E}$ & KX089330 \\
\hline & IM-2013-32879 & (7) Palermo, Sicily, Italy, $38^{\circ} 6.941^{\prime} \mathrm{N}, 13^{\circ} 21.676^{\prime} \mathrm{E}$ & KX089331 \\
\hline
\end{tabular}


the nucleus roughly corresponding to 0.25 whorls. The shape of the protoconch has been described but it should be borne in mind that in neogastropods with intracapsular development deformation of the larval shell is frequent (due e.g. to the presence of nurse eggs).

Radulae were dissected from selected specimens of Aplus dorbignyi and A. assimilis, cleaned with diluted bleach, rinsed in distilled water, mounted on stubs, air dried, coated with gold-palladium and examined with a scanning electron microscope.

\section{Sequencing and amplification}

DNA was extracted from a piece of muscle tissue using the DNeasy 96 Tissue kit (Qiagen). A fragment of cytochrome oxidase I (COI) mitochondrial gene was amplified using universal primers LCO1490 (5' GGTCAACAAATCATAAAGATATTGG-3') and HCO2198 (5'TAAACTTCAGGGTGACCAAAAAATCA-3') (Folmer et al. 1994). For some crucial specimens from West Africa, fixed in alcohol but thereafter preserved dried, which were unsuccessfully assayed with the pair HCO2198-LCO1490, we employed HCO2198 with the primer mlCOIint-F ( $5^{\prime}$-GGW ACWGGWTGAACWGTWTA Y CCY CC-3') designed to amplify a shorter fragment (ca. 300 bp) and employed in meta-barcoding works (Leray et al. 2013). All PCR reactions were performed in 25 $\mu \mathrm{L}$, containing $3 \mathrm{ng}$ of DNA, $1 \mathrm{X}$ reaction buffer, 2.5 $\mathrm{mM} \mathrm{MgCl2}, 0.26 \mathrm{mM}$ dNTP, $0.3 \mu \mathrm{M}$ of each primer, $5 \%$ DMSO and 1.5 units of Q-Bio Taq, QBiogene. Thermocycles consisted of an initial denaturation step at $94^{\circ} \mathrm{C}$ for $4^{\prime}$, followed by 40 cycles of denaturation at $94^{\circ} \mathrm{C}$ for $30^{\prime \prime}$, annealing at $48^{\circ} \mathrm{C}$ for $40^{\prime \prime}$ and extension at $72^{\circ} \mathrm{C}$ for $1^{\prime}$. The final extension was at $72^{\circ} \mathrm{C}$ for $5^{\prime}$. PCR products were purified and sequenced by the Eurofins sequencing facility. Both directions were sequenced to confirm accuracy of each sequence.

\section{Species delimitation and phylogenetic analyses}

Specimens suitable for DNA extraction were identified based on morphological features and according to the current taxonomy. COI sequences from the same specimens were then obtained, cleaned using Codon Code Aligner version 4.0.4, and automatically aligned using ClustalW implemented in BioEdit version 7.0.5.3 (Larkin et al. 2007). The accuracy of automatic alignments was confirmed by eye. To delimit species the online version of the Automatic Barcode Gap Discovery method (Puillandre et al. 2012; available at http://wwwabi.snv.jussieu.fr/public/abgd/) was used, with default parameters. It automatically detects, when present, a gap in the pairwise distribution of the genetic distances calculated between each pair of specimens. This gap, referred to as the barcode gap, is supposed to correspond to a threshold between intra- and interspecific distances and is used to propose species hypotheses in the form of molecular operative taxonomic units (MOTU).

The 66 new COI sequences, with the sequence retrieved from Genbank of Gemmula cf. cosmoi (Gas- tropoda, Conoidea, Turridae) (EU821220.1; voucher MNHN IM-2007-41424), Cancellopollia sp. (Gastropoda, Buccinoidea, Buccinidae) (EU015666.1; voucher MNHN IM-2009-17854), and Pisania striata (KX089332; voucher MNHN IM-2009-30664, Gastropoda, Buccinoidea, Buccinidae) as outgroups, yielded a 658 bp alignment (Table 1).

A Bayesian phylogenetic analysis was performed, with six Markov chains $\left(5 \times 10^{6}\right.$ generations each with a sampling frequency of one tree each hundred generations) in two parallel runs using Mr.Bayes version 3.1.2 (Ronquist and Huelsenbeck 2003). The GTR+I+G substitution model was used, as recommended by MrModeltest v.2.2 using the Akaike Information Criterion (Nylander 2004). The chain temperature was set at 0.02 . The convergence of each analysis was evaluated using Tracer 1.4.1 (Rambaut and Drummond 2007). A consensus tree was then calculated after omitting the first $25 \%$ trees as burn-in. The phylogenetic tree was used to test whether the species hypotheses proposed by ABGD corresponded to monophyletic groups or not.

\section{RESULTS}

In a first step, the shells of 66 specimens were grouped into four morphospecies (M1-M4) based on similarity of shell characters and according to the current taxonomy of the group. The specimens were thus assumed to represent the four currently recognized species (Fig. 2): Aplus scacchianus (Philippi, 1844) M1; A. dorbignyi (Payraudeau, 1826) - M2; A. scaber (Locard, 1892) - M3; A. assimilis (Reeve, 1846) - M4.

In a second step, COI sequences from the same specimens (including two shorter sequences of specimens BAU-2215.1 and BAU-2215.2, from Mauritania) were analysed with ABGD. Results were identical with or without the two shorter sequences. In the vicinity of the barcode gap found in the distribution of the pairwise genetic distances, ABGD provided consistent partitions of species hypotheses, regardless of the prior divergence threshold used. The more inclusive partitioning defined 7 species hypotheses (MOTU 1-7) and the less inclusive partitioning 13 (MOTU 1.1-7.2) (Fig. 1). In most cases, the additional group in the less inclusive partitioning corresponded to a single specimen with a slightly divergent sequence (a few nucleotides) from the most closely related ABGD group. One case only ABGD split a group of the more inclusive partition into two multi-specimen groups in the less inclusive partition, MOTU 1.2 and 1.3, deriving along with MOTU 1.1 from the more inclusive MOTU 1, and all together corresponding to M1 Aplus scacchianus (Fig. 2).

Each species hypothesis defined by ABGD and containing more than one specimen corresponded to a highly supported $(\mathrm{PP} \geq 0.96)$ clade in the Bayesian tree, except the clade that included the specimens identified as $A$. assimilis $(\mathrm{PP}=0.90)$.

Geographical data of the assayed specimens were then used to evaluate the geographical congruence of the species hypotheses. In the Gulf of Gabès, specimens belonging to MOTU 4 (morphologically identified as 


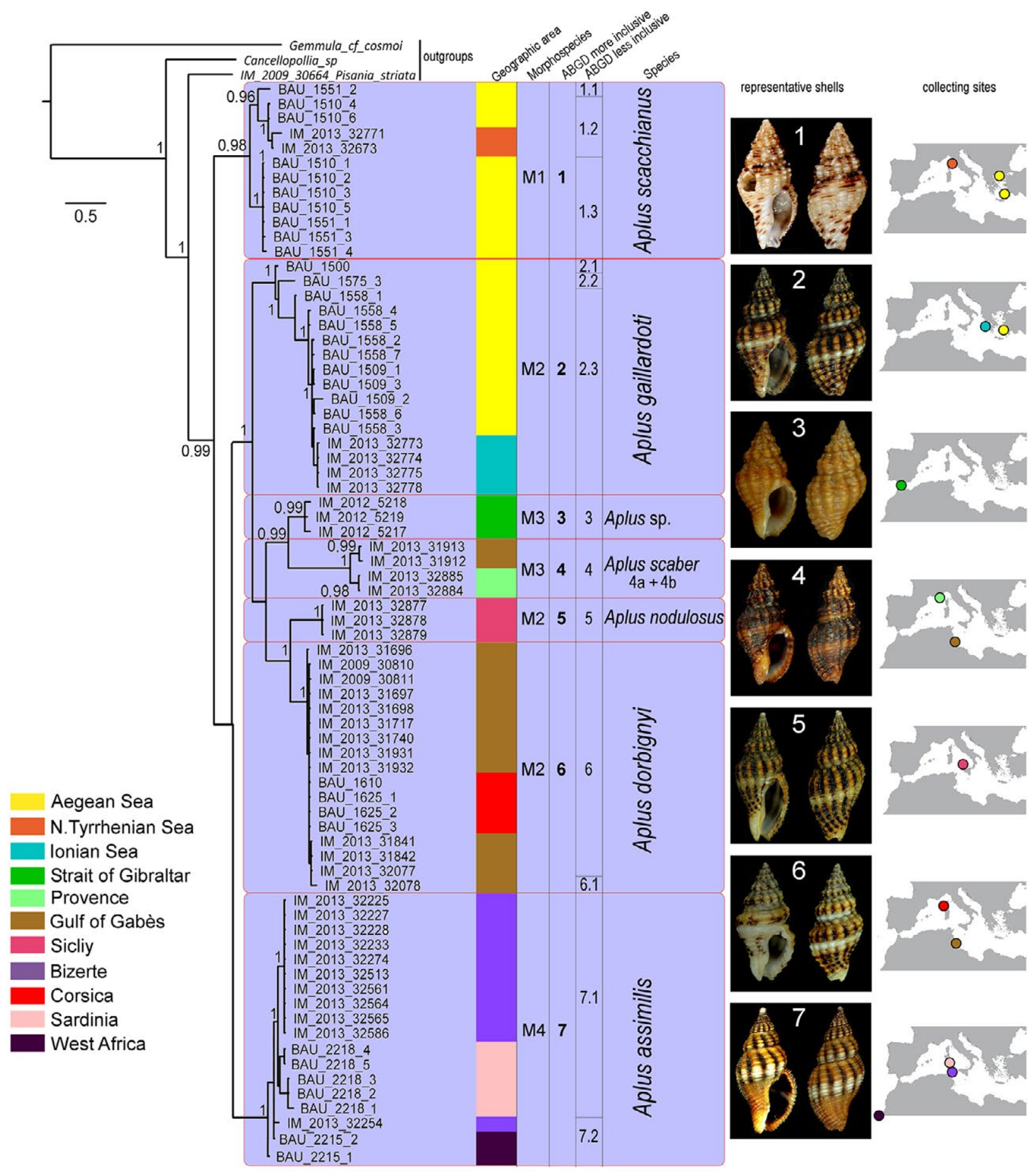

Fig. 2. - Bayesian phylogenetic tree based on the COI alignment (GTR+I+G model of evolution; $5 \times 10^{6}$ generations and $25 \%$ burn-in). Numbers at nodes indicate the Bayesian posterior supports (only values $>0.95$ are reported). Morphospecies (M1-M4) indicate the morphological primary identification of the assayed specimens. ABGD more and less inclusive partitions report the MOTUs (1-7 and 1.1-7.2, respectively) as molecularly identified. The shell of one assayed specimen for each of the seven major lineages is illustrated. Colour of collecting areas is also reported in the bars beside the tree and in the circles of the collecting sites on the small maps.

A. scaber) were sympatric with specimens belonging to MOTU 6 (morphologically identified as A. dorbignyi); in the Aegean Sea, specimens belonging to MOTU 1 (morphologically identified as A. scacchianus) were sympatric with specimens belonging to MOTU 2 (morphologically identified as A. gaillardoti).

Each of the seven species hypotheses proposed in the more inclusive ABGD partition included morpho- logically similar specimens. Additionally, when a species hypothesis was split into two or three in the less inclusive ABGD partition, no morphological difference was detected among them. However, two morphs were recognized within MOTU 4 (morphologically identified as A. scaber) in specimens from either Tunisia (Fig. 3I, J: less scabrous shells, nodules of lighter colour than interspaces) or France (Fig. 3K, L, broadly 
topotypical material, more scabrous sculpture and nodules darker than interspaces), and morphological differences were identified between MOTU 2 (morphologically identified as A. gaillardoti) and MOTU 5. Similarly, diagnostic features were identified for MOTU 3 from its sister group MOTU 4 (morphologically identified as A. scaber).

\section{DISCUSSION}

\section{Species delimitation}

We have employed an integrative taxonomy strategy for Mediterranean populations of the genus Aplus. A priori morphological identification of specimens was challenged by DNA data and then evaluated, and eventually consolidated by subsequent integration of geographic data and morphological features (protoconch and teleoconch morphology). Thus, in our delimitation approach, species are considered as hypotheses engaged in a process of validation as new characters are analysed (De Queiroz 2007, Barberousse and Samadi 2010).

The relative congruence between the species hypotheses defined with ABGD and the morphological and geographical data is a further support to the claim that ABGD can be used as a good proxy for species delimitation in gastropods when only molecular data are available (Puillandre et al. 2012, Barco et al. 2013, Prockow et al. 2013). Seven species hypotheses were eventually retained, corresponding to lineages that are divergent and reciprocally monophyletic, thus satisfying two of the criteria of species delimitation derived from the lineages species concept (Barberousse and Samadi 2010). The seven species hypotheses showed a geographical congruence that was of help to link some of them to available species names. MOTU 6 represented Aplus dorbignyi because it included topotypical (Payraudeau 1826) specimens from Corsica; MOTU 4 represented Aplus scaber because it included topotypical (Locard 1892) specimens from Saint Raphaël, France; MOTU 5 represented Aplus nodulosus (Bivona Ant., 1832) because it included topotypical specimens from Palermo. MOTU 2 was ascribed to Buccinum gaillardoti Puton, 1856, which was described from the eastern Mediterranean (Lebanon) although our material originated from the Aegean Sea (Greece). In all these cases, morphological features were not in contrast with the original descriptions. Finally, congruently with traditional taxonomy, MOTU 1 and MOTU 7 were unequivocally ascribed to Aplus scacchianus (Philippi, 1844) and Aplus assimilis (Reeve, 1856), respectively. MOTU 3, represented by three specimens from the Strait of Gibraltar (Tarifa), was morphologically compared with Aplus campisii (Ardovini, 2015), described from Sicily, but differences in the protoconch (high and protruding in A. campisii (Fig. 4D), low and dome-shaped in MOTU 3) and the teleoconch outline (more massive in MOTU 3 with the last whorl proportionally larger than in A. campisii) warrant distinction.

\section{Systematics}

Class Gastropoda Cuvier, 1797

Subclass Caenogastropoda Cox, 1960

Order Neogastropoda Thiele, 1929

Family Buccinidae Rafinesques, 1815

Subfamily Pisaniinae Gray, 1857

Genus Aplus de Gregorio, 1885

Type species: Murex plicatus Brocchi, 1814 by subsequent designation of Vokes (1971: 83).

Diagnosis. Shell of small size for the family (height 10-20 mm), ovate, slender, spire about half total height. Protoconch paucispiral, of 1-1.5 smooth mamillate to dome-shaped whorl. Teleoconch with axial, orthocline, nodulose ribs, and spiral cords. Siphonal canal short. Aperture ovate; outer lip thickened, crenulated externally, the inner side with strong denticles, the apicalmost and the parietal delimiting a posterior "anal canal".

The radulae of Aplus dorbignyi and A. assimilis were rather similar: rachiglossate, central tooth almost as long as wide, cutting edge with five cusps, three close to each other and spaced in the central part, central cusp largest, the others increasingly smaller. Lateral tooth fang-like, with two cusps; outer margin rounded and broadened; inner cusp with a smooth, strongly curving outer flank and a convex inner broadside with two denticles.

Remarks. The type species of Aplus has been designated by Vokes as Murex plicatus forma serzus de Gregorio, 1885, from the Pliocene of Italy, based on Bellardi (1872: pl. 12 Fig. 21). Brunetti and Della Bella (2014) overlooked Vokes' designation and instead indicated Aplus nilus (de Gregorio, 1885) (as Murex plicatus Brocchi, 1814 non Linnaeus, 1758) as type species. The two entities are unquestionably related and the concept of the genus Aplus remains exactly the same regardless of the type species, perfectly fitting its use for the Recent species dealt with herein. In addition to Anna (a nomen dubium based on a type species, Anna massena, that is quite probably a conoidean; see above), these species were previously assigned to Pollia or Cantharus. The genus Pollia (type species Buccinum undosum Linnaeus, 1758, type locality Asia; by monotypy) differs by its small labral tooth located along the edge of the outer lip, and the presence of denticles on the columellar plait (Vermeij and Bouchet 1998). The genus Cantharus (type species Buccinum tranquebaricum Gmelin, 1791, type locality SE India; by subsequent designation), differs in the larger, less slender and more robust shell, with a wider aperture and simple outer lip (Vermeij 2006). Landau and Vermeij (2012) erected a new genus, Ameranna, which should be applied to Miocene-Recent western Atlantic species very similar to Aplus (the Recent Ameranna florida (García, 2008), Am. milleri (Nowell-Usticke, 1959), Am. royalensis (Watters, 2009), Am. willemsae (De Jong and Coomans, 1988) and Am. capixaba (Coltro and Dornellas, 2013) plus at least one Miocene and one Pliocene species). The major difference would 

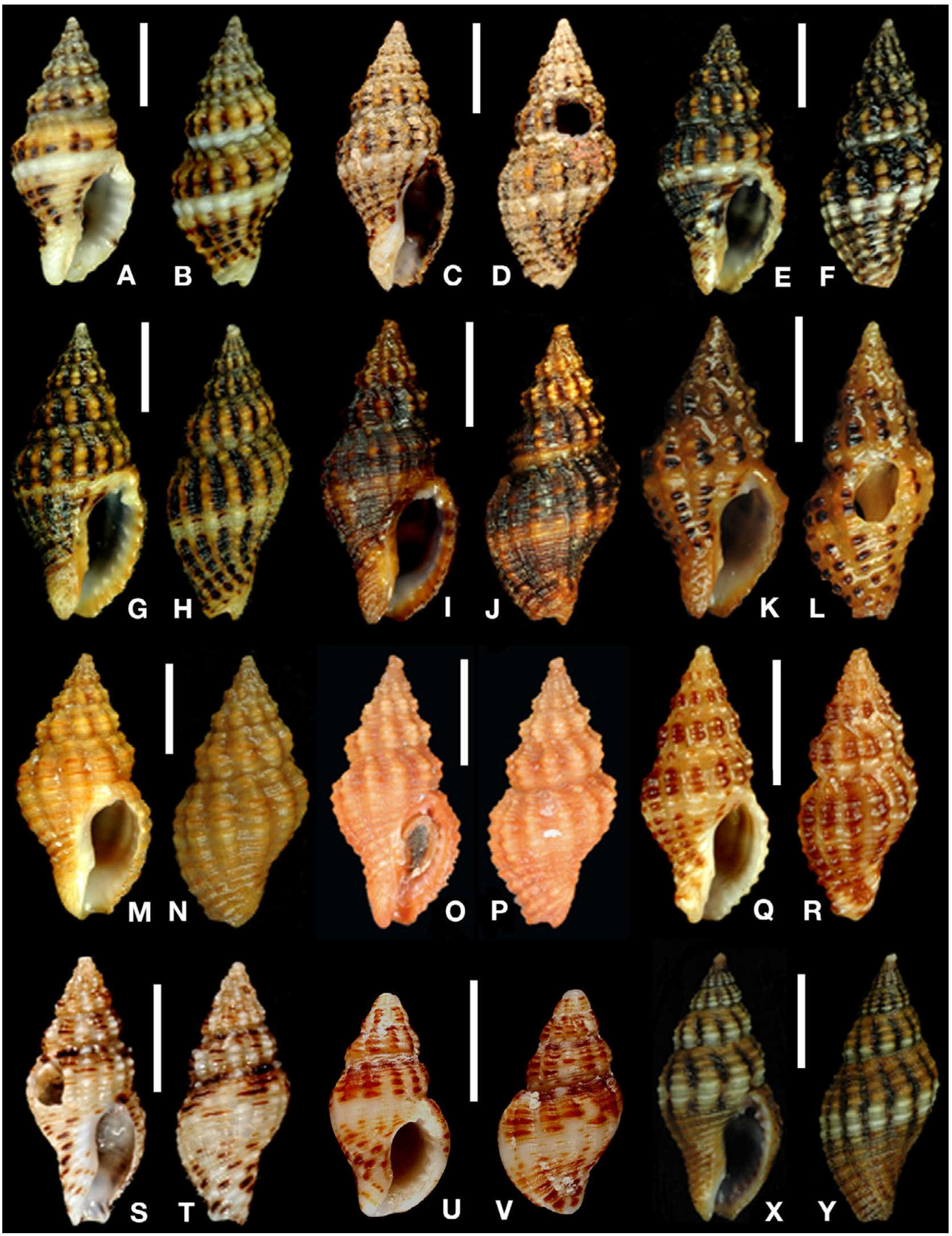

Fig. 3. - Shell morphological variation in the Aplus dorbignyi complex. A, B, Aplus dorbignyi, Djerba, Tunisia (MNHN); C, D, Aplus dorbignyi Calcatoggio, Corsica (neotype MNHN IM-2000-31672); E, F, Aplus gaillardoti, Paxos Is. (MNHN); G, H, Aplus nodulosus, Palermo, Sicily (neotype MNHN IM-2013-32887); I, J, Aplus scaber, Djerba, Tunisia (MNHN); K, L, Aplus scaber, Saint Raphaël, France MNHN; M, N, Aplus sp., Tarifa, Spain (MNHN); O, P, Aplus campisii, southeastern Sicily (holotype, Malacologia Mostra Mondiale, Cupra Marittima: photo courtesy T. Cossignani); Q, R, Aplus scaber, Toulon, France (syntype MNHN IM-2000-27765); S, T, Aplus scacchianus, Elba Is. (MNHN); U, V, Aplus scacchianus, probable syntype of $P$. picta Scacchi (MNHN IM-2000-31884); X, Y, Aplus assimilis, Bizerte, Tunisia (MNHN). Scale bars $5 \mathrm{~mm}$. 
be in the inner side of the outer lip, lyrate in Ameranna v. denticulate in Aplus. The actual relationships of Ameranna and Aplus and their status are worthy of investigation by molecular data.

The anatomy of these species has not been investigated. Broad similarity in radular features of A. dorbignyi and $A$. assimilis indicates uniformity throughout the genus, but small differences (e.g. stouter teeth in $A$. assimilis) suggest caution and invite to further investigate finer variation of this character among species.

Aplus dorbignyi (Payraudeau, 1826) Figs 3A-D, 4A, 5D-F

Buccinum dorbignyi Payraudeau, 1826: 159, pl. 8, figs 4, 6.

Type material: What remains of the Payraudeau collection is in MNHN but it does not contain types of Buccinum dorbignyi, which must be considered lost. To stabilize the nomenclature of the group, we herein designate as neotype a sequenced specimen (MNHN IM2000-31672), from Tour d'Ancône, Calcatoggio, Corsica.

Type locality: Payraudeau originally cited Buccinum dorbignyi from the "golfes d'Ajaccio, de Valinco, de Ventilegne" on the southwest coast of Corsica. The neotype comes from the Gulf of Sagone, just north of Ajaccio.

Material examined: 4 specimens from Calcatoggio, Corsica (MNHN IM-2000-31672 [neotype], BAU-1625-1, BAU-1625-2, BAU-1610), and 13 specimens from Gulf of Gabès (MNHN IM2013-31696, IM-2013-31697, IM-2013-31698, IM-2013-31717, IM-2013-31740, IM-2013-31931, IM-2013-31932, IM-201331841, IM-2013-31842, IM-2013-32077, IM-2013-32078, IM2009-30840, IM-2013-30811).

Description (data of neotype in parentheses). Shell of medium size for the genus, height 15-20 mm (17.5), ovate, slender, last whorl 3/5 total height. Protoconch paucispiral, of 1.5 smooth mamillate whorls, height $500 \mu \mathrm{m}$, width $650 \mu \mathrm{m}$. Teleoconch of 5-6 (5.5) convex whorls, base moderately constricted, suture impressed. Axial sculpture of orthocline, nodulose ribs, slightly sinuous anteriorly, broader than interspaces, 12-14 (12) on the first whorl, 11-14 (12) on the last whorl. Spiral sculpture of numerous cords and cordlets, thinner than axials, irregularly spaced, and of varying size, the abapical thinner than the adapical, 2 cords and various corldets on the first whorls, 10-13 (12) on the last whorl. Siphonal canal short, notched, fasciole low rounded. Aperture ovate, columellar wall concave medially, twisted and with 2-3 (2) weak plications anteriorly, with a parietal denticle posteriorly; outer lip thickened, the inner side with 8-9 (8) strong denticles, the posteriormost stronger than the parietal, together delimiting a posterior canal. Colour yellow to orange, with dark brown to black axial interspaces, a white spiral band on the medial part of the spire. Periostracum thin, brown, easily lost after death.

Distribution. Mediterranean Sea; records from eastern Mediterranean to be checked genetically (may be misidentified A. gaillardoti, see below).

Remarks. Aplus dorbignyi is easily separated from Aplus scacchianus by its stronger sculpture, its nonspotted colour pattern and its larger size. It is larger than Aplus scaber, its sculpture is not so pronounced, and the white band in the middle of the last whorl is usually missing in Aplus scaber. As noticed by Brunetti and Della Bella (2014), the fossils from the Upper Pleistocene of Capo Milazzo (Sicily) figured by Ruggieri and Greco (1965: pl. 2, figs 3a, b) are the only fossils known for the species.

\section{Aplus nodulosus (Bivona Ant., 1832)} Fig. 3G, H

Pisania nodulosa Bivona Ant., 1832: 13; pl. 2 fig. 8

Type material: There is no original Bivona material known to us. To stabilize nomenclature, we herein designate as neotype a sequenced specimen, MNHN IM-2013-32877.

Type locality: Palermo, Sicily.

Material examined: 3 specimens from Sicily, Palermo (MNHN IM2013-32877, IM-2013-32878, IM-2013-32879)

Description (data of neotype in parentheses). Shell of medium size for the genus height 18-21 mm (21), ovate, slender spire 3/5 total height. Protoconch paucispiral, of 1.5 smooth mamillate whorls. Teleoconch of 5-6 (5.8) convex whorls, base moderately constricted, suture impressed. Axial sculpture of orthocline, nodulose ribs, slightly sinuous anteriorly, as broad as or slightly broader than interspaces, 9-11 (9) on the first whorl, 12-13 (13) on the last whorl. Spiral sculpture of numerous cords and cordlets, thinner than axials, irregularly spaced, and of varying size, the abapical thinner than the adapical, 2 cords and various corldets on the first whorls, 11-13 (12) on the last whorl. Siphonal canal short, notched, fasciole low rounded. Aperture ovate, columellar wall straight, barely twisted and with 3 weak plications anteriorly, with a parietal denticle posteriorly; outer lip thickened, the inner side with 7-8 (7) denticles, the posteriormost stronger than the parietal, together delimiting a posterior canal. Colour creamy orange, with dark brown to black axial interspaces, a white spiral band on the medial part of the spire. Periostracum thin, brownish, easily lost after death.

\section{Distribution. Currently known only from Sicily.}

Remarks. The name Pisania nodulosa has been sunken in the synonymy of Pollia dorbignyi since the second half of the 19th century. Bivona-Bernardi (1832) provided a good illustration that, combined with the type locality, leaves no doubt that it is applicable to our topotypical material. The name Turbinella eburnea O.G. Costa, 1830 is also cited in the synonymy of Pollia dorbignyi; however, the description is superficial, there is no illustration, and we treat it as a nomen $d u$ bium (in case a neotype is designated, we recommend that a specimen of $A$. dorbignyi be selected to avoid nomenclatural problems). Aplus nodulosus can hardly be diagnosed morphologically from A. dorbignyi, the latter showing usually (not always) a less pronounced sculpture, a slightly stouter slender shell with the last whorl never exceeding half of total height. However, while the Tunisian and Corsican specimens ascribed to A. dorbignyi were always grouped in a single species 


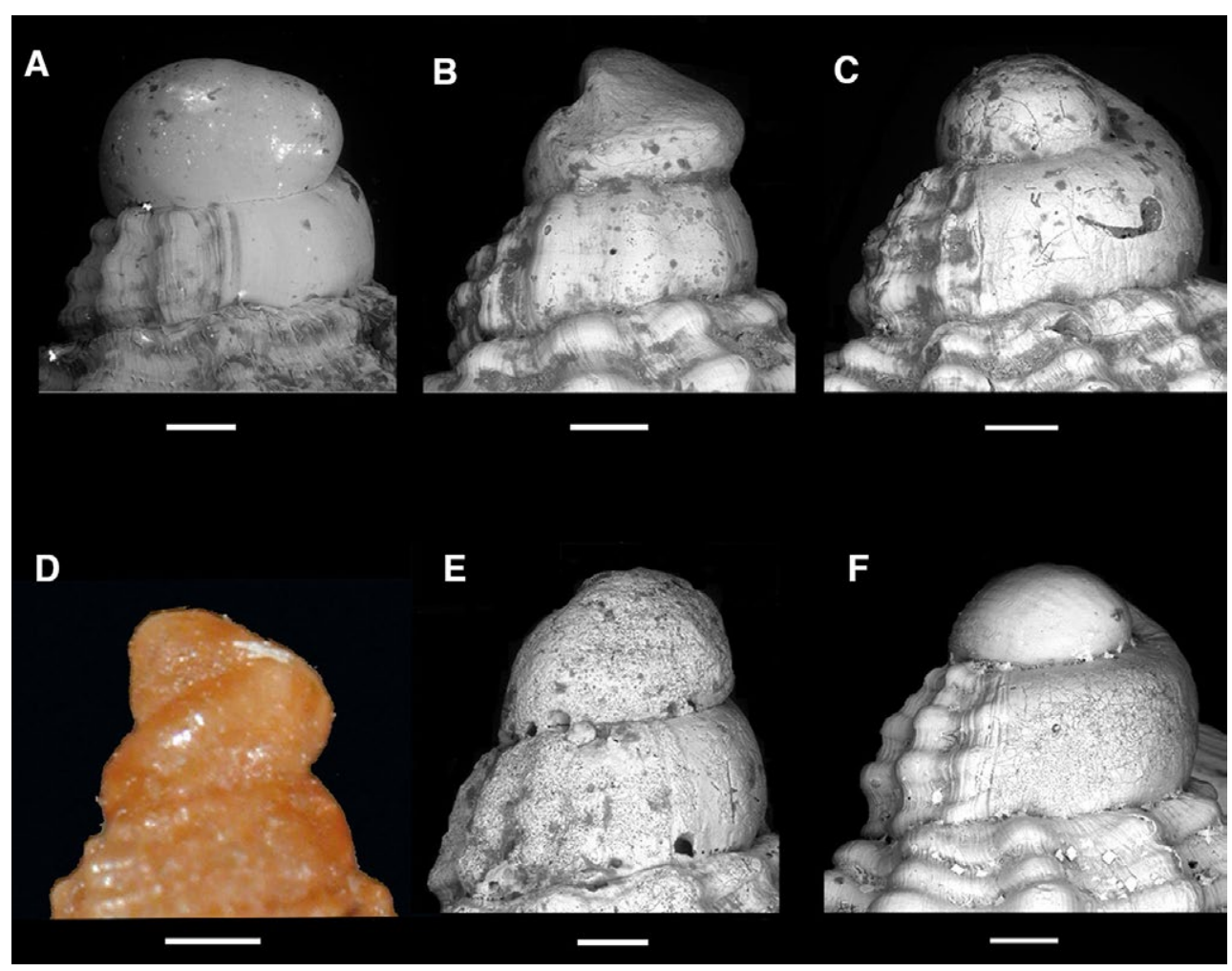

Figs 4. - Protoconch morphology in the Aplus dorbignyi complex. A, Aplus dorbignyi, Djerba, Tunisia (MNHN IM-2013-31697); B, Aplus scaber, Djerba, Tunisia (MNHN IM-2013-31913); C, Aplus sp., Tarifa, Spain (MNHN IM IM-2009-5219); D, Aplus campisii, southeastern Sicily (holotype, Malacologia Mostra Mondiale, Cupra Marittima: photo courtesy T. Cossignani); E, Aplus assimils, Bizerte, Tunisia (MNHN IM-2013-32513); F, Aplus scacchianus, Elba Is., Italy (MNHN IM-2013-32673). Scale bars $200 \mu \mathrm{m}$.

hypothesis, the geographically intermediate Sicilian specimens corresponding to A. nodulosus were strongly separated genetically in all analyses. Aplus gaillardoti (Puton, 1856) comb. nov.
Fig. 3E, F

Buccinum gaillardoti Puton, 1856: 224-225

Type material: The whereabouts of Puton's original material are not known and the type of Buccinum gaillardoti is certainly lost. However, because we do not have molecular material from Lebanon, we refrain from designating a neotype.

Type locality: Saida, Lebanon.

Material examined: 2 specimens (BAU-1500, BAU-1575.3) from Analypsi, Aegean Sea; 10 specimens (BAU-1558.1, BAU-1558.4, BAU-1558.5, BAU-1558.2, BAU-1558.7, BAU-1509.1, BAU1509.3, BAU-1509.2, BAU-1558.6, BAU-1558.2) from Astypalea, Aegean Sea; 4 specimens (MNHN IM-2013-32773, IM-201332774, IM-2013-32775, IM-2013-32778) from Paxos Island, Ionian Sea, Greece.

Description. Shell of medium size for the genus, height 10-12 mm, ovate, slender, spire about 3/5 total height. Protoconch paucispiral, of 1.5 smooth mamillate whorls, height $500 \mu \mathrm{m}$, width $650 \mu \mathrm{m}$. Teleoconch of 5-6 evenly convex whorls, base moderately constricted, suture impressed. Axial sculpture of orthocline, nodulose ribs, slightly sinuous anteriorly, as broad as interspaces, 13-14 on the first whorl, 13-14 on the last whorl. Spiral sculpture of numerous cords and fine cords, thinner than axials, irregularly spaced, and of varying size, the abapical thinner than the adapical, 3 cords and various corldets on the first whorls, 10-11 on the last whorl. Siphonal canal short, notched, fasciole low, rounded. Aperture ovate, columellar wall concave medially, weakly twisted and with 2-3 weak plications anteriorly, with a parietal denticle posteriorly; outer lip thickened, the inner side with 8 strong denticles, the posteriormost stronger than the parietal, together delimiting a posterior canal. Colour dark orange to black, with dark brown to black axial interspaces, and a white spiral band on the medial part of the spire. Periostracum thin, dark brown to black, easily lost after death.

Distribution. Eastern Mediterranean, from Greek Ionian and Aegean Seas to Lebanon.

Remarks. Aplus gaillardoti is smaller than A. nodulosus, darker and the white spiral band appears already on the first teleconch whorl, and not only on the last adult whorl as in A. nodulosus. Aplus gaillardoti is also similar to A. dorbignyi but is smaller, the sculpture is more pronounced, and the colour pattern is darker.

\section{Aplus scaber (Locard, 1892)}

Figs 3I-L, Q, R, 4B

Pollia scabra Locard, 1892: 103.

Type material: 3 syntypes in MNHN: 1 from Marseille (MNHN IM2000-27764) and 2 from Toulon (MNHN IM-2000-27765).

Type locality: Mediterranean coast of France.

Material examined: the type material; 2 specimens from Djerba (Gulf of Gabès; MNHN IM-2013-31912, IM-2013-31913); 2 
specimens from Saint Raphaël (France; MNHN IM-2013-32885, IM-2013-3884).

Description. Shell of medium size for the genus, height $12-15 \mathrm{~mm}$, ovate, slender, last whorl 3/5 of total height. Protoconch paucispiral, of 1.5 smooth mamillate whorls, height $800 \mu \mathrm{m}$, width $700 \mu \mathrm{m}$. Teleoconch of 5-6 convex whorls, base moderately constricted, suture impressed. Axial sculpture of orthocline, not elevated, nodulose ribs, broader than interspaces, 7-9 stronger on the first whorl, 11-13 weaker on the last whorl. Spiral sculpture of numerous primary cords and secondary fine cords, thinner than axials, irregularly spaced, 2-4 cords on the first whorls, 10-13 cords and 5-12 secondary fine cords on the last whorl. Siphonal canal short, notched. Aperture ovate, columellar wall concave medially, twisted and with 2-3 weak plications anteriorly, with a parietal denticle posteriorly; outer lip thickened, the inner side with 8-9 strong denticles, the posteriormost stronger than the parietal, together delimiting a posterior canal. Colour yellow-orange to light brown, with brown to dark brown nodules arranged in two spiral rows above the medial part, and a series of spiral rows below the medial part; medial area without dark nodules sometimes with a lighter spiral band. Periostracum very thin, light brown, easily lost after death.

Distribution. Probably broadly distributed in the Mediterranean but distribution not known in detail because of confusion with the other species. Known with certainty from the coasts of France, southern Italy and the Gulf of Gabès (present study). Recorded from Spain (Gofas et al. 2011) but that material should be tested genetically due to similarity to the samples from Gibraltar (MOTU 3 -Aplus sp.).

Remarks. Aplus scaber differs from A. dorbignyi, A. gaillardoti and A. nodulosus in its finer and more acute tubercles (making its sculpture more scabrous even if less pronounced), and the less evident medial spiral band, usually lighter in colour but not white, sometimes lacking. It is also smaller than A. dorbignyi. Darker nodules with lighter interspaces (as in the type material) have been reported as diagnostic with most other species (with lighter nodules and darker interspaces); however, this feature is variable and nodules of the same colour as the interspaces are not so rare. The specimens from Gabès lack the plications on the columella, and have a less scabrous sculpture than usual $A$. scaber, but probably represent merely atypical morphotypes as is known for many gastropod species in the Gulf of Gabès.

Aplus sp.

Figs 3M, N, 4C

Material examined: 3 specimens from Tarifa (Strait of Gibraltar; MNHN IM-2009-5219, IM-2009-5217, IM-2009-5219).

Description. Shell of medium size for the genus, height $15-18 \mathrm{~mm}$, ovate, slender, spire about $3 / 5$ total height. Protoconch paucispiral, of 1.5 smooth domeshaped whorls, height $740 \mu \mathrm{m}$, width $860 \mu \mathrm{m}$. Tel- eoconch of 5-6 evenly convex whorls, base moderately constricted, suture impressed. Axial sculpture of orthocline, nodulose ribs, slightly sinuous anteriorly, as broad as interspaces, 13-14 on the first whorl, 13-14 on the last whorl. Spiral sculpture of numerous cords and fine cords, thinner than axials, irregularly spaced, and of varying size, the abapical thinner than the adapical, 3 cords and various cordlets on the first whorls, 6-9 on the last whorl. Siphonal canal short, notched, fasciole low, rounded. Aperture ovate, columellar wall concave medially, weakly twisted and with 2-3 weak plications anteriorly, with a parietal denticle posteriorly; outer lip thickened, the inner side with 8 strong denticles, the posteriormost stronger than the parietal, together delimiting a posterior canal. Colour dark orange to black, with dark brown to black axial interspaces, a white spiral band on the medial part of the spire. Periostracum thin, dark brown to black, easily lost after death.

Distribution. Currently known only from the Strait of Gibraltar (present study).

Remarks. The sequenced material from the Strait of Gilbraltar showed resemblance to both the molecularly close Aplus scaber, and the types and other Sicilian material of Aplus campisii. Differences in protoconch and teleoconch morphology (mamillate v. domeshaped protoconch, and less scabrous sculpture, stouter and non-monochromatc shell in the Strait of Gibraltar specimens) suggest rather a stronger morphological affinity to its sister species, Aplus scaber. Pending the availability of more material (including also comparative topotypical molecular material of $A$. campisii), we conservatively refrain from describing a new species. Furthermore, Aplus campisii differs from A. dorbignyi, $A$. gaillardoti and $A$. nodulosus in its finer and more acute tubercules (making its sculpture more scabrous even if less pronounced) and in the almost completely monochrome shell. It differs from A. scaber in its more neatly monochrome and lighter orange-yellowish shell.

Aplus assimilis (Reeve, 1846) comb. nov. Figs 3X, Y, 4E, 5A-C

Buccinum assimile Reeve, 1846: Buccinum pl. 12, species 90

Type material: Not searched for the present study, presumably in The Natural History Museum, London.

Type locality: no locality was given by Reeve.

Material examined: 11 sequenced specimens from Bizerte (MNHN IM-2013-32254, IM-2013-32225, IM-2013-32227, IM-201332228, IM-2013-32233, IM-2013-32274, IM-2013-32513, IM2013-32561, IM-2013-32564, IM-2013-32565, IM-2013-32568).

Description. Shell of medium size for the genus, height 14-16 mm, ovate, slender spire about half total height. Protoconch paucispiral, of 1 smooth mamillate whorl. Teleoconch of 5-6 convex whorls, base moderately constricted, suture impressed. Axial sculpture of orthocline, nodulose ribs, slightly sinuous anteriorly, larger than interspaces, 9-11 on the first whorl, 13-14 on the last whorl. Spiral sculpture of numerous cords, thinner than axials, irregularly spaced, and of varying 


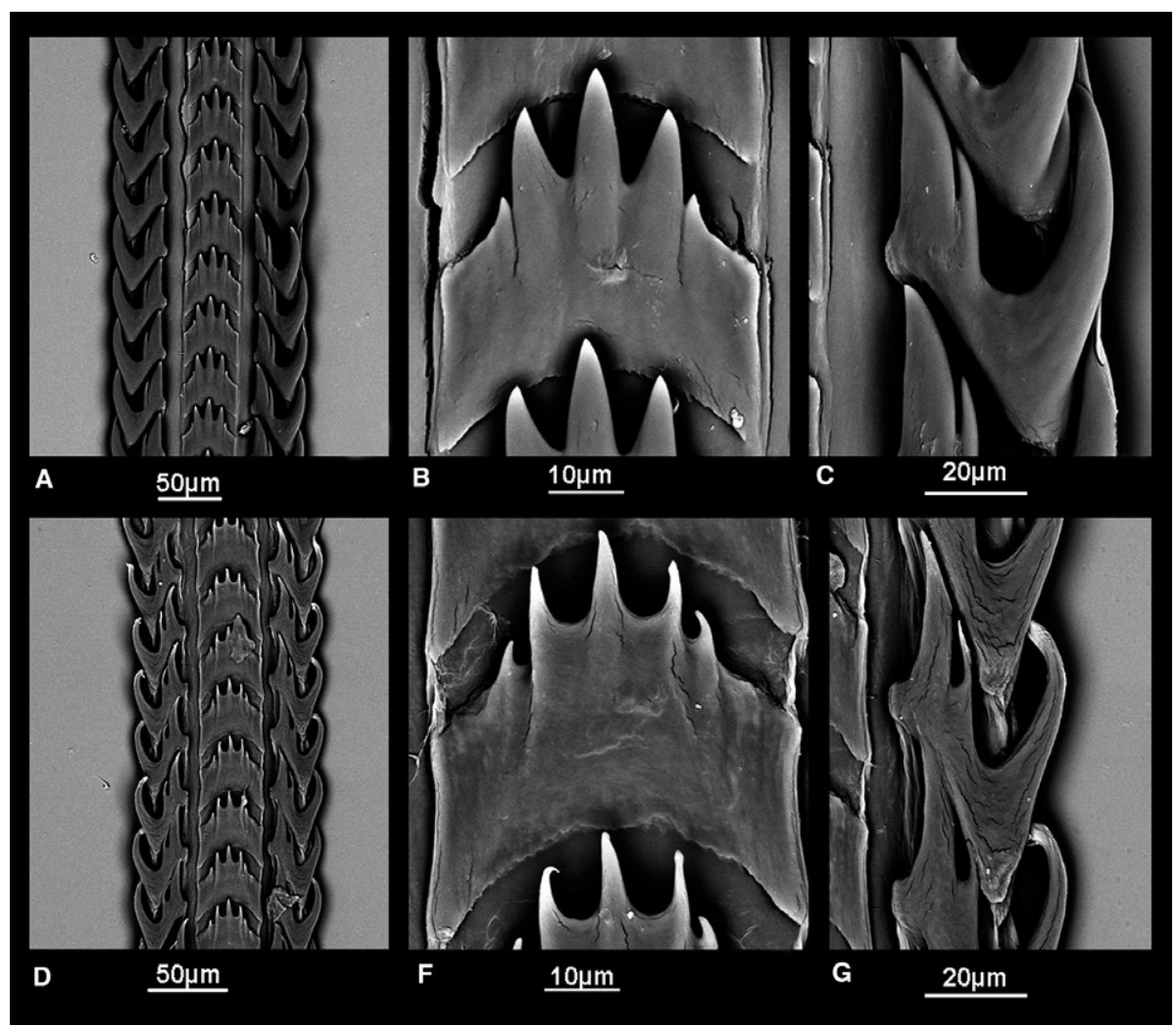

Fig. 5. - Morphology of radula with detail of central and lateral teeth in the Aplus dorbignyi complex. A-C, Aplus assimils, Bizerte, Tunisia (MNHN IM-2013-32513). D-E, Aplus dorbignyi, Djerba, Tunisia (MNHN M-2013-31697). Scale bars 50 um (A, D), 10 um (B, E) and 20 $\mu \mathrm{m}(\mathrm{C}, \mathrm{F})$.

size, the abapical thinner than the adapical, 4-5 on the first whorl, 15-18 on the last whorl. Siphonal canal short, notched, fasciole low, rounded. Aperture ovate, columellar wall concave medially, twisted anteriorly; outer lip thickened, the inner side with 8 strong denticles, the posteriormost stronger than the parietal, together delimiting a posterior canal. Colour yellow to orange, with dark brown to black axial interspaces, a white spiral band on medial part of the spire.

Distribution. West African coast; Mediterranean Sea: previously reported from the Ebro Delta, Spain (Quiñonero Salgado and López Soriano 2014) and Sardinia (Nappo and Loi 2015); now also Bizerte, Tunisia (present study).

Remarks. Aplus assimilis differs from A. dorbignyi, A. gaillardoti, A. nodulosus, A. scaber and A. campisii in its more rounded whorls and less pronounced sculpture. This species was long known from the eastern Atlantic and is commonly found along the African coasts and in the Canary Islands (Poppe and Goto 1991, Ardovini and Cossignani 2004, Hernández et al. 2011). It has been only recently recorded from the Mediterranean, off the Ebro Delta in Spain and in southern Sardinia. The present record from northeastern Tunisia (Bizerte) is based on specimens collected in 2014. We cannot decide at present whether we are dealing with a species that only recently arrived into the Mediterranean, or whether it was so far unrecognized due to its similarity to the other variable native species of Aplus.
Aplus scacchianus (Philippi, 1844)

Figs 3S-V, 4F

Purpura picta Scacchi, 1836 (invalid name: homonym of Purpura picta Turton, 1825)

Buccinum scacchianum Philippi, 1844 (nom. nov. pro Purpura picta Scacchi, 1836, non Turton, 1825)

Type material: probable syntype (MNHN IM-2000-31884) labelled "Pisania picta Scac./type de Phil." with another handwritten label glued on it "Buccinum scacchianum Phil."; no material at the Zological Museum of Naples University (Cretella et al. 2004).

Type locality: Posilippo, near Naples, Italy.

Material examined: 1 sequenced specimen from Isola d'Elba, Italy (MNHN IM-2013-32673), 1 sequenced specimen from Marmaros Halkadikci, Greece (MNHN IM-2013-32771), 10 sequenced specimens from Astypalea, Aegean Sea, Greece (BAU-1551.2, BAU151.4, BAU-1510.6, BAU-1510.1, BAU-1510.2, BAU-1510.3, BAU-1510.5, BAU-1551.1, BAU-1551.3, BAU-1551.4).

Description. Shell of small-medium size for the genus, height 10-15 mm, ovate, slender, last whorl 3/5 total height. Protoconch paucispiral, of 1.5 smooth mamillate whorls, height $715 \mu \mathrm{m}$, width $760 \mu \mathrm{m}$. Teleoconch of 5-6 convex whorls, base moderately constricted, suture evident but not impressed. Axial sculpture of orthocline, not elevated, nodulose ribs, broader than interspaces, 10-12 on the first whorl, 15-17 on the last whorl. Spiral sculpture of numerous primary cords and secondary fine cords, thinner than axials, regularly spaced, 4 cords on the first whorls, 20-23 cords and 5-10 secondary fine cords on the last whorl. Siphonal canal short, notched. Aperture ovate, columellar wall concave medially, twisted and with 1-2 plications an- 
teriorly, with a parietal denticle posteriorly; outer lip thickened, the inner side with 8-9 strong denticles, the posteriormost stronger than the parietal, together delimiting a posterior canal. Colour whitish, with brown to dark brown spots irregularly set; a medial area without dark spots or with lighter ones. Periostracum thin, light brown, easily lost after death.

Distribution. Western Mediterranean Basin; Aegean Sea, Greece (Poppe and Gotto 1991).

Remark. Aplus scacchianus is the most distantly related among the species of this group (it is the sister to all the others in the molecular tree). It differs from all the remaining species in its smaller size and more slender shell. Additionally, the colour pattern of brown to dark brown spots irregularly set is also diagnostic. A single shell at MNHN may be part of materials sent to Petit de la Saussaye by A. Scacchi (the handwriting "Pisania picta Scac." is the same as on the label accompanying syntypes of "Pleurotoma concinna Scac."). Although Cretella et al. (2004) raised doubts on the type status of several of such Scacchi's lots at MNHN, we rather see no counter-indications in using those materials for lectotype designation in case of need.

\section{CONCLUSION}

We have recognized eight distinct species of Aplus in the Mediterranean, of which seven were represented by DNA samples in our dataset. With the exception of Aplus scacchianus, which is clearly well separated both morphologically and phylogenetically, the other species revealed a pattern of relationships congruent with that of other complexes of Mediterranean gastropods. The complex of Aplus dorbignyi includes in fact a species of clearly Atlantic origin, namely Aplus assimilis, which is also the sister to the remaining species of the complex. Then the complex includes one species confined to the eastern Mediterranean (Aplus gaillardoti), one so far known only from Sicily (A. nodulosus) and two with broad western Mediterranean ranges (A. scaber, A. dorbignyi), one known so far only from Alboran Sea and A. campisii (not assayed genetically) from Sicily. The relatively large genetic divergence among the species of this complex $(>10 \%)$, notwithstanding their morphological similarity (and the frequently overlapping morphological variation) is not infrequent in Mediterranean gastropods. Similar patterns have been recently observed in the sessile vermetids of the genus Dendropoma (Calvo et al. 2009, 2015) and in the small muricids of the genus Ocinebrina (Barco et al. 2013). The fossil history of this complex is documented by a relatively large record (Brunetti and Della Bella 2014), which would be crucial to date nodes of molecular phylogenetic hypotheses and then infer biogeographical dynamics. However, it is here highlighted that, similar to what occurs with the small mussel drills Ocinebrina (Barco et al. 2013), classification of fossil shells of Aplus might underestimate actual diversity and probably requires more sophisti- cated tools (e.g. morphometrics) to disentangle their actual variation.

\section{ACKNOWLEDGEMENTS}

The material for molecular studies in this paper were derived partly from field work in the Gulf of Gabès and we are grateful to the participants in the MNHN workshop "GABES 2012-2013", Philippe Maestrati, Emmanuel Vassard, Gianni Spada, and Jean-Pierre Miquel, for their help in sampling. Our special thanks to Konag Kyriakos, Peter Stahlschmidt, Jean-Pierre Miquel, Andrea Nappo and Serge Gofas for collecting material respectively in Greece, Sicily, Sardinia, France and Alboràn. Virginie Héros, Barbara Buge and Philippe Maestrati helped with the curation of vouchers and access to MNHN historical material. We also thank Yuri Kantor, Serge Gofas and Gianni Spada for their help in the morphological analysis and their taxonomic expertise. Tiziano Cossignani is acknowledged for the photographs of Aplus campisii. This work was carried out in part at the Service de Systématique Moleculaire (UMS 2700 CNRS, MNHN), and we acknowledge the assistance of Delphine Gey during molecular manipulations. Part of the specimens were processed during practice of the 2015 course in Marine Biodiversity methods at 'Sapienza' University, and we acknowledge the work of the students. The first author would like to acknowledge the support of Prof. Moncef Boumaiza, who supervised her $\mathrm{PhD}$ research at MNHN. Serge Gofas and José Templado are heartily thanked for very useful suggestions and criticisms.

\section{REFERENCES}

Amio M. 1963. A comparative embryology of marine gastropods, with ecological considerations. J. Shimonoseki Univ. Fish. 12: 229-355.

Ardovini R. 2015. Descrizione di una nuova specie di Pollia dalla Sicilia Sud-orientale. Malacologia Mostra Mondiale 86: 12-13.

Ardovini R., Cossignani T. 2004. West African Seashells. L'Informatore Piceno, Ancona, $319 \mathrm{pp}$.

Barberousse A., Samadi S. 2010. Species from Darwin onward. Integr. Zool. 5: 187-197. http://dx.doi.org/10.1111/j.1749-4877.2010.00204.x

Barco A., Houart R., Bonomolo G., et al. 2013. Molecular data reveal cryptic lineages within the northeastern Atlantic and Mediterranean small mussel drills of the Ocinebrina edwardsii complex (Mollusca: Gastropoda: Muricidae). Zool. J. Linn. Soc. 169: 389-407. http://dx.doi.org/10.1111/zoj.12069

Bellardi L. 1872. Molluschi dei terreni Terziari deI Piemonti e della Liguria. Parte I. Gasteropoda (Muricidae et Tritonidae). Stamperia Reale, Torino, $264 \mathrm{pp}$. http://dx.doi.org/10.5962/bhl.title.12269

Bivona-Bernardi A. 1832. Caratteri d'un nuovo genere di conchiglie della famiglia delle Columellarie del Signor de Lamarck. Effemeridi Scientifiche e Letterarie per la Sicilia 2: 8-13.

Bouchet P., Gofas S. 2015. Buccinidae Rafinesque, 1815. In: MolluscaBase 2015. Accessed on 2016-04-27 through: World Register of Marine Species at

h t t p : / / w w w. marinespecies.org/a p hi a. php? $\mathrm{p}=$ taxdetailsandid $=149$

Brunetti M.M., Della Bella G. 2014. La famiglia Buccinidae Raphinesque, 1815 nel Plio-Pleistocene italiano: i generi Aplus De Gregorio, 1884, Engina Gray, 1839 e Gemophos Olsson and Harbinson, 1953 (Gastropoda). Boll. Malacol. 42: 118-120.

Calvo M., Templado J., Oliverio M., et al. 2009. Hidden Mediterranean biodiversity: molecular evidence for a cryptic species complex within the reef building gastropod Dendropoma pe- 
traeum (Mollusca: Caenogastropoda). Biol. J. Linn. Soc. 96: 898-912.

http://dx.doi.org/10.1111/j.1095-8312.2008.01167.x

Calvo M., Alda F, Templado J., et al. 2015. Surviving the Messinian Salinity Crisis? Divergence patterns in the genus Dendropoma (Gastropoda: Vermetidae) in the Mediterranean Sea. Mol. Phylogenet. Evol. 91: 17-26. http://dx.doi.org/10.1016/j.ympev.2015.05.004

Claremont M., Williams S.T., Barraclough T.G., et al. 2011. The geographic scale of speciation in a marine snail with high dispersal potential. J. Biogeogr. 38: 1016-1032. http://dx. doi.org/10.1111/j.1365-2699.2011.02482.x

Cretella M., Crovato C., Crovato P., et al. 2004. The malacological work of Arcangelo Scacchi (1810-1893). Part II: a critical review of Scacchian taxa. Boll. Malacol. 40: 114-131.

De Queiroz K. 2007. Species concepts and species delimitation. Syst. Biol. 56: 879-886. http://dx.doi.org/10.1080/10635150701701083

Folmer O., Black M., Hoeh W., et al. 1994. DNA primers for amplification of mitochondrial cytochrome c oxidase subunit I from diverse metazoan invertebrates. Mol. Mar. Biol. Biotech. 3: 294-299.

García E.F. 2008. Four new buccinid species (Gastropoda: Buccinidae) from the Western Atlantic. Novapex 9: 141-148.

Giannuzzi-Savelli R., Pusateri F., Palmeri A., et al. 2003. Atlante delle conchiglie marine del Mediterraneo. Vol. 4 (Neogastropoda: Muricoidea). Rome, Evolver. 298 pp.

Gofas S., Le Renard J. (eds) 2015. CLEMAM: Check List of European Marine Mollusca. Available from: http://www.somali. asso.fr/clemam/index.clemam.html (accessed 31 October 2015)

Gofas S., Moreno D., Salas C. (eds) 2011. Moluscos marinos de Andalucia: Vol. I. Servicio de Publicaciones e Interscambio Cientifico Universidad de Málaga, Málaga, 342 pp.

Golikov A.N. 1980. Molluscs Buccininae of the world Ocean. Fauna of the USSR, Mollusca, 5: 1-465, + 42 pls.

Hayashi S. 2005. The molecular phylogeny of the Buccinidae (Caenogastropoda: Neogastropoda) as inferred from the complete mitochondrial $16 \mathrm{~S}$ rRNA gene sequences of selected representatives. Molluscan Res. 25: 85-98.

Hernández J.M., Rolán E., Swinnen F., et al. 2011. Moluscos y conchas marinas de Canarias. ConchBooks, Hackenheim, 716 pp.

Landau B., Vermeij G.J. 2012. The genera Engina and Ameranna nov. gen. (Mollusca: Gastropoda, Buccinoidea, Buccinidae, Pisaniinae) from the Western Atlantic Neogene. Cainozoic Res. 9: 121-133.

Larkin M.A., Blackshields G., Brown N.P., et al. 2007. Clustal W and Clustal X version 2.0. Bioinformatics 23: 2947-2948. http://dx.doi.org/10.1093/bioinformatics/btm404

Leray M., Yang J.Y., Meyer C.P., et al. 2013. A new versatile primer set targeting a short fragment of the mitochondrial COI region for metabarcoding metazoan diversity: application for characterizing coral reef fish gut contents. Front. Zool. 10: 34. http://dx.doi.org/10.1186/1742-9994-10-34

Locard A. 1892. Les coquilles marines des côtes de France. Paris, Bailliére, $384 \mathrm{pp}$.
Nappo A., Loi S. 2015. First record of Pollia assimilis (Reeve, 1846) (Gastropoda: Buccinidae) from Italy. Boll. Malacol. 51: 87-90.

Nylander J.A.A. 2004. MrModeltest v2. Program distributed by the author. Evolutionary Biology Centre, Uppsala University.

Payraudeau B.C. 1826. Catalogue descriptif et méthodique des annélides et des mollusques de l'ile de Corse. Paris. 218 pp.

Poppe G.T., Goto Y. 1991. European seashells. Vol. 1. Verlag Christa Hemmen, Wiesbaden, 221 pp.

Prockow M., Mackiewicz P., Pienkowska J.R. 2013. Genetic and morphological studies of species status for poorly known endemic Trochulus phorochaetius (Bourguignat, 1864) (Gastropoda: Pulmonata: Hygromiidae), and its comparison with closely related taxa. Zool. J. Linn. Soc. 169: 124-143. http://dx.doi.org/10.1111/zoj.12048

Puillandre N., Baylac M., Boisselier M.C., et al. 2009. An integrative approach to species delimitation in Benthomangelia (Mollusca: Conoidea). Biol. J. Linn. Soc. 96: 696-708. http://dx.doi.org/10.1111/j.1095-8312.2008.01143.x

Puillandre N., Lambert A., Brouillet S., et al. 2012. ABGD automatic barcode gap discovery for primary species delimitation. Mol. Ecol. 21: 1864-1877. http://dx.doi.org/10.1111/j.1365-294X.2011.05239.x

Quiñonero Salgado S., López Soriano J. 2014. Moluscos continentales del delta del Ebro (Cataluña, España). Spira 5: 121-132.

Rambaud A., Drummond A.J. 2007. Tracer, version 1.4. Available from http://beast.bio.ed.ac.uk/Tracer

Ronquist F., Huelsenbeck J.P. 2003. MrBayes 3: Bayesian phylogenetic inference under mixed models. Bioinformatics 19: $1572-1574$.

http://dx.doi.org/10.1093/bioinformatics/btg180

Ruggieri G., Grec A. 1965. Studi geologici e paleontologici su Capo Milazzo con particolare riguardo al Milazziano. Geologica Romana 4: 41-88.

Scaperrotta M., Bartolini S., Bogi C. 2012. Accrescimenti. Stadi di accrescimento dei molluschi marini del Mediterraneo. Vol. IV. L'Informatore Pliceno, Ancona, $184 \mathrm{pp}$.

Settepassi F., 1971. Atlante malacologico I molluschi marini viventi nel Mediterraneo. Vol. 2. Roma, INIVAG, 295 pp.

Vermeij G.J. 2006. The Cantharus group of Pisaniinae buccinid gastropods: review of the Oligocene to Recent genera and description of some new species of Gemophos and Hesperisternia. Cainozoic Res. 4: 71-96

Vermeij G.J., Bouchet P. 1998. New Pisaniinae (Mollusca, Gastropoda, Buccinidae) from New Caledonia, with remarks on Cantharus and related genera. Zoosystema 20: 471-785.

Webber H.H. 1977. Gastropoda: Prosobranchia. In: Giesc A.C., Pearse J.S. (eds), Reproduction of Marine Invertebrates, Molluscs: Gastropods and Cephalopods, vol. IV. Academic Press. Elsevier. pp. 1-97. http://dx.doi.org/10.1016/B978-0-12-282504-0.50007-X

Zou S., Li Q., Kong L. 2012. Monophyly, distance and characterbased multigene barcoding reveal extraordinary cryptic diversity in Nassarius: a complex and dangerous community. PLoS ONE 7: e47276.

http://dx.doi.org/10.1371/journal.pone.0047276 